Website : http://dayamas.unmermadiun.ac.id/index.php/dayamas

\title{
Strategi Pemberdayaan Lahan Pekarangan di Kelurahan Banjarejo Kota Madiun
}

\author{
Luluk Sulistiyo Budi ${ }^{1)}$, Praptiningsih Gamawati Adinurani ${ }^{2)}$ \\ ${ }^{1,2}$ ) Prodi Agroteknologi, Universitas Merdeka Madiun, Jl. Serayu No.79, Madiun, 63133 \\ I)E-mail: luluksb@unmer-madiun.ac.id \\ ${ }^{2)}$ E-mail: praptiningsih@unmer-madiun.ac.id
}

\begin{abstract}
There are several factors that make yard empowerment less attractive to the community, so it is necessary to explore these problems from several aspects. Methods of implementing community service include (a) socialization of yardland empowerment that supports the RPL program and knowing the level of perception of prospective trainees, (b) plant cultivation training, (c) plant cultivation demonstration plots in the yard, and (d) assistance in managing yardland in a manner sustainable. The results of community service activities showed that after participating in the training there was (a) an increase in farming knowledge. (b) increasing the use of yardland by planting food crops, vegetable plants, ornamental plants or medicinal plants in accordance with land ownership (c) periodic assistance to support the sustainability of the yardland empowerment program
\end{abstract}

Keywords-: community service; demonstration plots; plant cultivation; yardland;

\section{PENDAHULUAN}

Pekarangan merupakan lahan terbuka yang ada di sekitar rumah tinggal. Lahan pekarangan jika difungsikan dengan baik akan memberikan lingkungan yang menarik dan bermanfaat bagi kehidupan keluarga. Wabah penyakit Covid-19 menyebabkan sebagian besar masyarakat beraktifitas di dalam rumah. Hal ini menimbulkan rasa jenuh jika berdiam diri di rumah dalam jangka waktu cukup lama. Untuk mengatasi kebosanan tersebut dapat dilakukan kegiatan memanfaatkan lahan pekarangan. Hal ini sejalan dengan salah satu strategi Kementerian Pertanian RI dalam menghadapi pandemi Covid-19 yaitu mengoptimalkan lahan pekarangan. Lahan pekarangan rumah tangga dapat dimanfaatkan secara optimal untuk lumbung pangan keluarga, baik sebagai penyedia sumber pangan nabati atau bahan pangan hewani (Qomariah, 2020). Ketahanan pangan keluarga di saat dan pasca pandemi Covid-19 menjadi penting untuk memenuhi kebutuhan pangan sekaligus meningatkan imunitas tubuh anggota keluarga.

Program-program pemberdayaan masyarakat terkait dengan pemanfatan lahan pekarangan dikenal dengan Rumah Pangan Lestari (RPL). Program RPL sudah dilaksanakan sesuai dengan peraturan, namun hasil program tersebut secara umum masih belum maksimal. Permasalahan yang muncul pada program RPL yaitu kurangnya keterampilan masyarakat dalam menjalankan program RPL (Tyas, 2019). Di beberapa RPL tidak ada tindak lanjut, artinya tidak ada kegiatan lagi setelah program RPL selesai. Putri, $d k k$. (2015) mengemukakan hasil evaluasi pada RPL Girimoyo, Karangploso, Malang bahwa tingkat indeks keberlanjutan program RPL hanya 63,84\%. Hal ini diduga dipengaruhi oleh beberapa faktor diantaranya pola pikir sasaran, terbatasnya pengetahuan, terbatasnya sarana dan prasarana dan juga terbatasnya pemahaman pemasaran hasil. Faktor tidak adanya pendampingan sampai pasca program RPL berdampak pada terhambatnya pemberdayaan lahan pekarangan. Seperti yang dikemukakan oleh Tyas (2019) bahwa sedikitnya pemahaman mengenai teknologi produksi atau teknik budidaya tanaman oleh peserta program RPL dan jarang dilakukan kegiatan pendampingan dan pelatihan menyebabkan program RPL terhenti 
Website : http://dayamas.unmermadiun.ac.id/index.php/dayamas

begitu saja. Adanya sistem paket benih/bibit tanaman menyebabkan hasil tanaman beragam namun dalam jumlah sedikit sehingga tidak dapat dikomersialkan (Fityanti $d k k$., 2020).

Permasalahan-permasalahan tersebut memerlukan upaya nyata untuk sinkronisasi kegiatan yang dilakukan oleh beberapa pihak sehingga pemberdayaan lahan pekarangan dapat berlangsung dengan maksimal. Oleh karena itu perlu strategi dalam pemberdayaan lahan pekarangan agar kegiatan RPL tetap berkesinambungan.

\section{METODE PELAKSANAAN}

Pelaksanaan pengabdian dilakukan di Kelurahan Banjarejo Kota Madiun. Kelurahan Banjarejo termasuk dalam wilayah Kecamatan Taman dengan luas area 12,46 $\mathrm{km}^{2}$ yang merupakan wilayah paling besar diantara kecamatan lainnya (BPS Kota Madiun, 2020) sedangkan Kelurahan Banjarejo mempunyai luas $1,83 \mathrm{~km}^{2}$ (BPS Kota Madiun, 2021). Pelaksanaan kegiatan pengabdian pada bulan Oktober - Desember 2020 meliputi :

1. Sosialisasi pemberdayaan lahan pekarangan penunjang program RPL sekaligus mengetahui tingkat persepsi calon peserta pelatihan

2. Pelatihan dengan tatap muka tentang budidaya tanaman

3. Demplot budidaya tanaman pangan di pekarangan

4. Pendampingan pengelolaan lahan pekarangan secara keberlanjutan

\section{HASIL DAN PEMBAHASAN}

Pelaksanaan kegiatan pengabdian telah dilakukan sesuai dengan jadwal yang telah ditentukan. Hasil kegiatan mencakup beberapa hal

\section{A. Sosialisasi Pemberdayaan Lahan Pekarangan}

Sosialisasi ini dilakukan dalam rangka untuk mengetahui tingkat persepsi peserta pelatihan terhadap pengertian, fungsi, dan manfaat lahan pekarangan. Sosialisasi dilakukan di Gedung Pusat Pendidikan Masyarakat Kelurahan Banjarejo yang dihadiri oleh ketua-ketua RT, Ibu rumah tangga dan karang taruna lingkungan Kelurahan Banjarejo khususnya RW I (Gambar 1 dan Gambar 2).

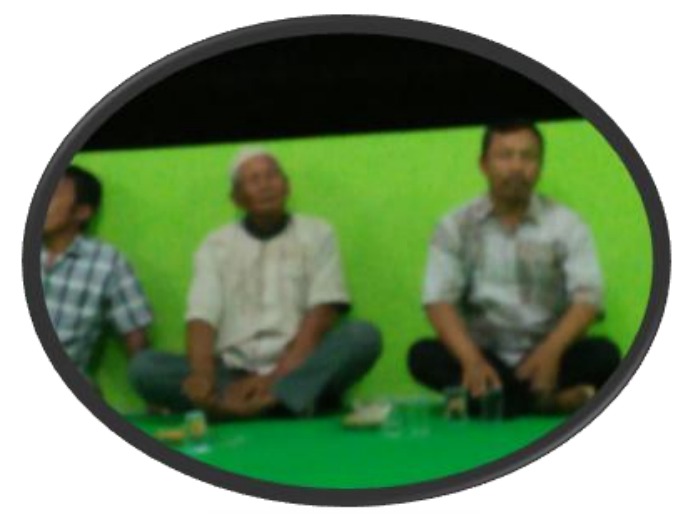

Gambar 1. Koordinasi Kegiatan Sosialisasi 


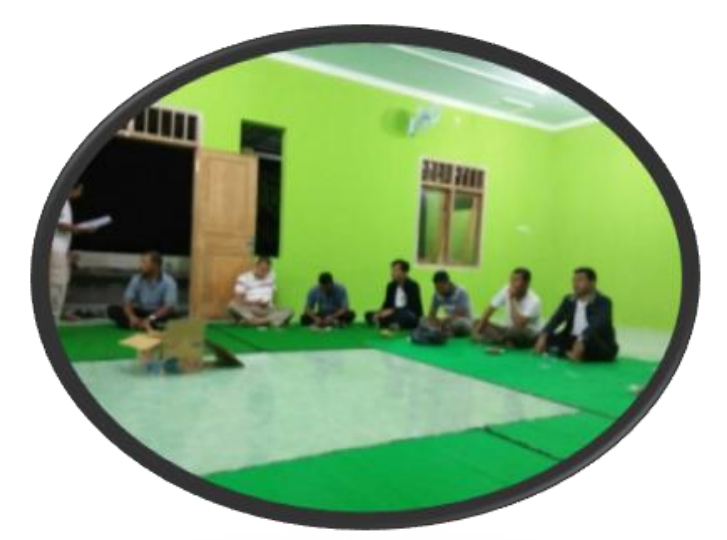

Gambar 2. Sosialisasi Pemberdayaan Lahan Pekarangan

Untuk menentukan langkah-langkah pendampingan pengelolaan lahan pekarangan berkelanjutan, maka dilakukan observasi terhadap kriteria peserta. Hasil observasi menunjukkan peserta berasal dari berbagai kalangan menurut jenjang pendidikan (Gambar 3), umur (Gambar 4), pekerjaan (Gambar 5), jenis tanaman yang dibudidayakan (Gambar 6) dan luas lahan pekarangan (Gambar 9).

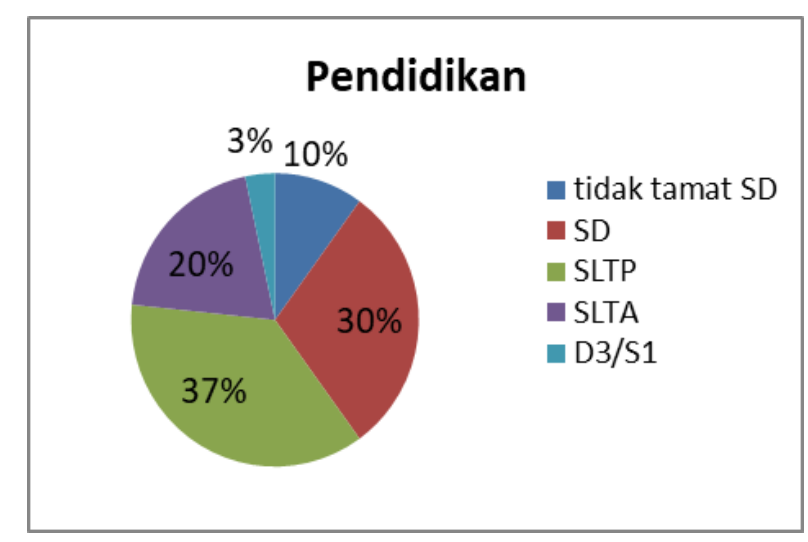

Gambar 3. Jenjang Pendidikan Peserta Sosialisasi

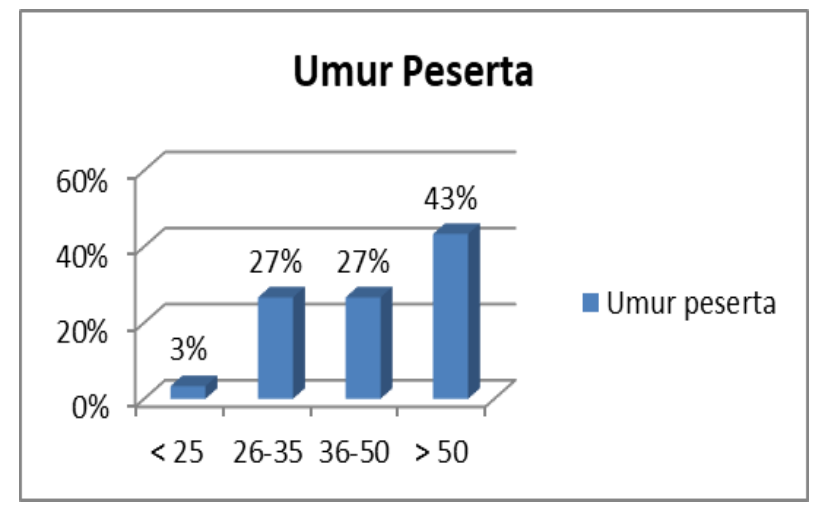

Gambar 4. Berbagai Umur Peserta Sosialisasi 
Website : http://dayamas.unmermadiun.ac.id/index.php/dayamas

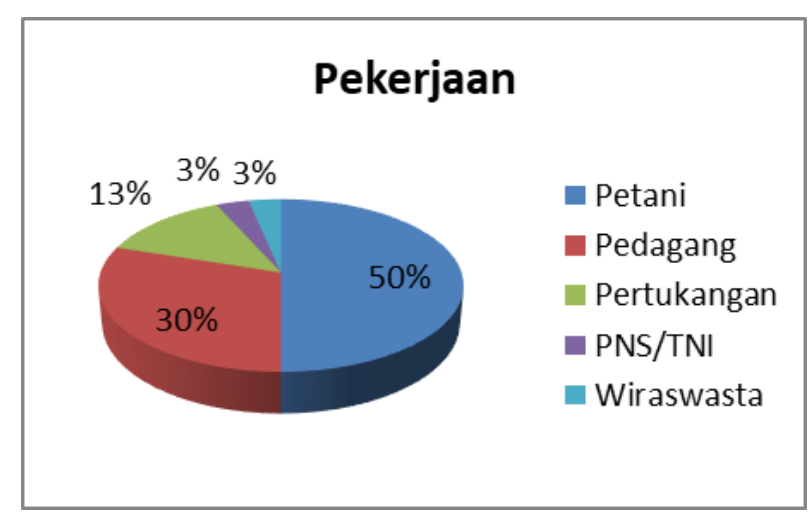

Gambar 5. Jenis Pekerjaan Peserta Sosialisasi

Sosialisasi diikuti oleh 30 peserta dengan jenjang pendidikan mulai dari tidak tamat SD sampai tingkat Sarjana, dan terbanyak dari tingkat SMP sekitar $37 \%$. Meskipun $60 \%$ peserta memiliki jenjang pendidikan SLTP ke bawah, namun peserta antusias mengajukan pertanyaan-pertanyaan berkaitan dengan pemberdayaan lahan pekarangan. Demikian pula usia dan jenis pekerjaan peserta sosialisasi bervariasi mulai usia kurang 25 th sampai lebih dari 50 th dengan jenis pekerjaan petani, pedagang, pertukangan, PNS dan wiraswasta. Usia peserta didominasi diatas 50 th $(43 \%)$ dan peserta lebih banyak dari kalangan wiraswasta. Hal ini mungkin peserta di usia lebih 50 th sudah berkurang kegiatan pokoknya dan peserta dengan pekerjaan wiraswasta lebih fleksibel mengatur waktu untuk beraktifitas.

Hasil penyuluhan dan diskusi menggambarkan bahwa selama ini peserta lebih memanfaatkan pekarangan dengan tanaman hias sebagai keindahan saja seperti terlihat pada Gambar 6.

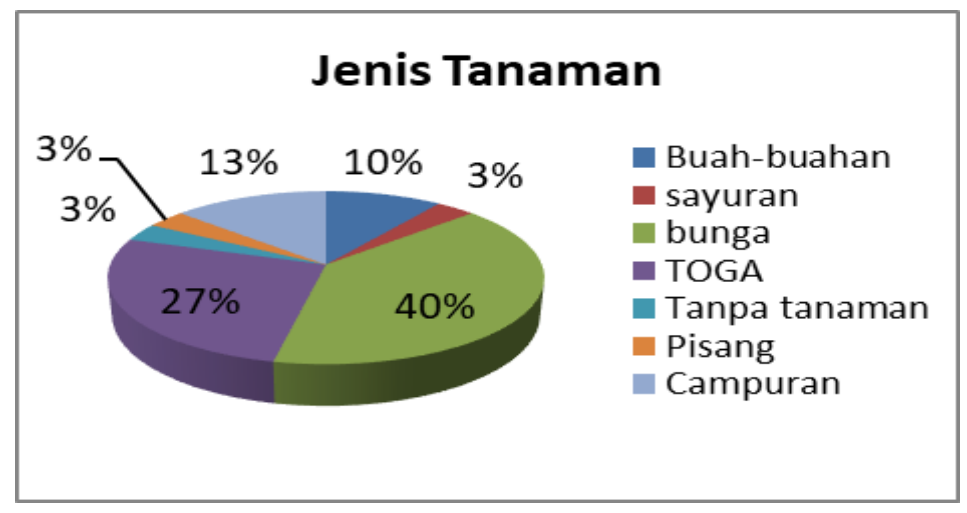

Gambar 6. Luas Pekarangan Peserta Sosialisasi

Peserta sosialisasi sebanyak $40 \%$ menanam bunga atau tanaman hias, hanya sebatas untuk estetika namun tidak terpikir kearah komersial. Sebenarnya jika dioptimalkan pemberdayaan lahan pekarangan untuk tanaman hias dapat menghasilkan income. Apalagi pada masa pandemi terjadi pembatasan aktifitas sehingga banyak ibu-ibu mempunyai banyak waktu luang untuk menata tanaman di halaman rumah. Penjualan tanaman hias meningkat tajam dan muncul beraneka species tanaman hias yang viral dengan harga fantatis. Menurut Gunawan dan Sayaka (2020), tanaman hias yang laku keras saat ini yaitu jenis tanaman bercorak unik (variegata) seperti janda bolong (Monstera adansonii variegated) dan jenis Monstera variegated (Monvar) lainnya. Untuk tanaman jenis variegata, harga bisa dibanderol gila-gilaan, bahkan hingga puluhan juta rupiah per pot. Namun, untuk tanaman jenis ini, 
Website : http://dayamas.unmermadiun.ac.id/index.php/dayamas

Ia menuturkan tak dapat mematok harga pasti karena setiap tanaman memiliki keunikannya sendiri.

Dengan adanya sosialisasi peserta banyak yang akan memberdayakan lahan pekarangannya. Lahan pekarangan yang sudah mengalami pavingisasi masih bisa diberdayakan untuk budidaya tanaman dengan menggunakan pot/polybag atau vertikultur (Gambar 7 dan gambar 8).

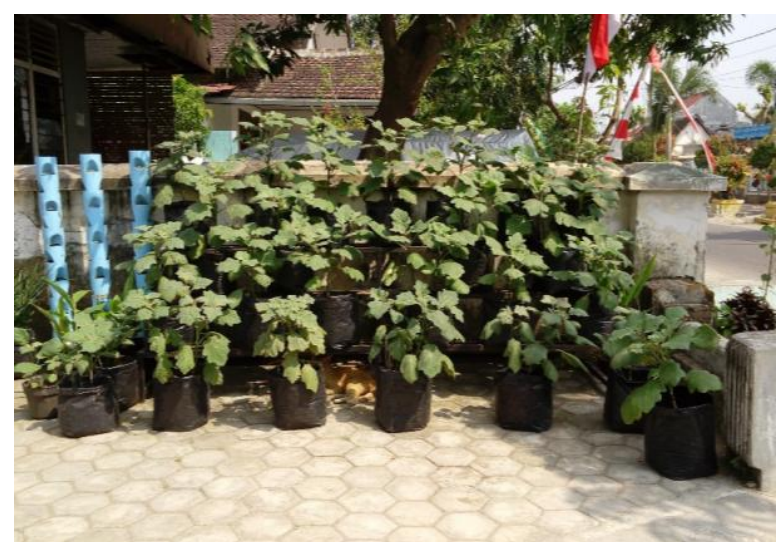

Gambar 7. Budidaya Sayuran di Pekarangan Paving

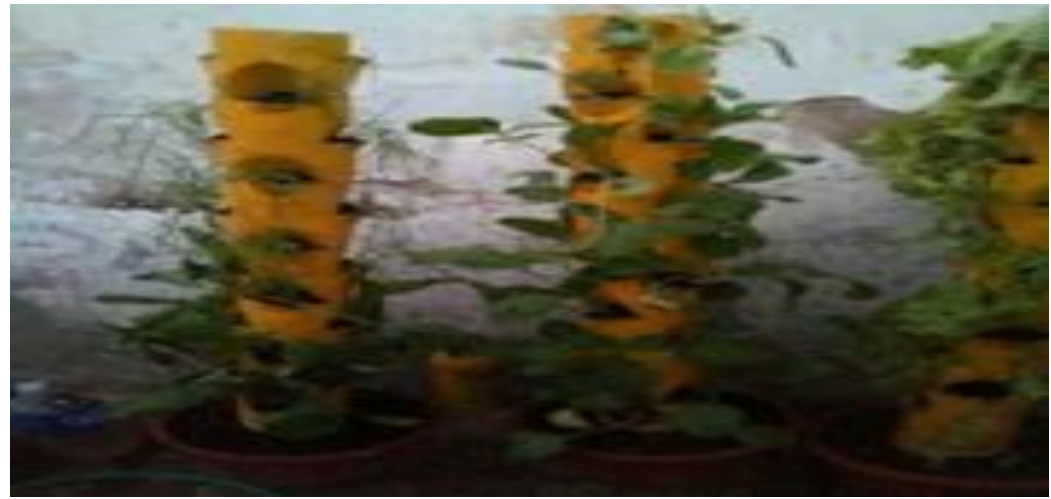

Gambar 8. Budidaya Sawi Vertikultur

Selama ini peserta mempunyai pola pikir bahwa membudidayakan tanaman pangan atau tanaman sayuran harus dilakukan pada lahan pekarangan yang luas sehingga banyak lahan pekarangan yang tidak dimanfaatkan atau tidak produktif. Kepemilikan luas lahan pekarangan tersaji pada Gambar 9. 
Website : http://dayamas.unmermadiun.ac.id/index.php/dayamas

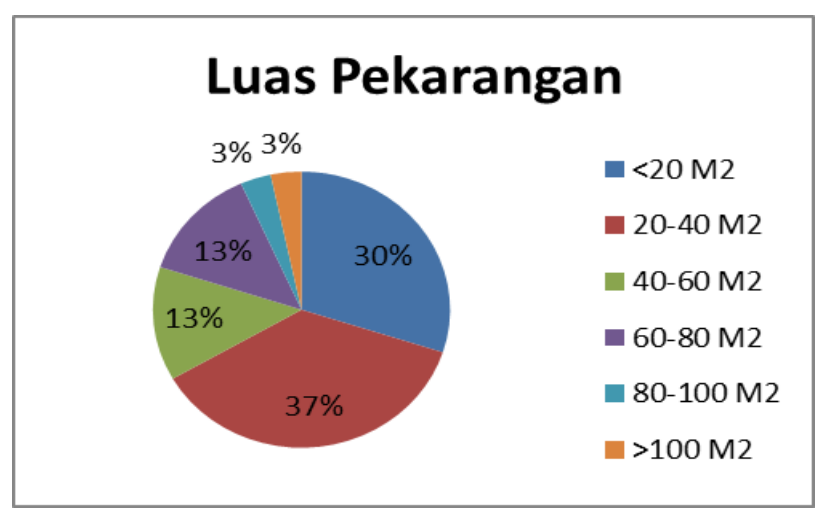

Gambar 9. Luas Pekarangan Peserta Sosialisasi

Peserta paling banyak memiliki lahan pekarangan seluas antara $20 \mathrm{~m}^{2}-40 \mathrm{~m}^{2}$ yaitu $37 \%$ dan yang memiliki lahan dengan luas $<20 \mathrm{~m}^{2}$ cukup banyak pula $(30 \%)$. Keterbatasan lahan pekarangan tidak menjadi pembatas atau halangan untuk tidak melakukan kegiatan budidaya tanaman di rumah. Rumah tanpa lahan pekaranganpun masih dapat melakukan kegiatan bercocok tanam. Dengan perkembangan teknologi budidaya tanaman, memungkinkan bercocok tanam tanpa lahan. Kepemilikan lahan pekarangan berapapun luasnya masih dapat difungsikan asal pemilik lahan mempunyai semangat, niat dan pemahaman budidaya tanaman di lahan pekarangan dengan mengikuti pelatihan-pelatihan.

B. Pelatihan Budidaya Tanaman di Lahan Pekarangan

Pelatihan budidaya tanaman khusus di lahan pekarangan dimaksudkan untuk meningkatkan pengetahuan dan keterampilan peserta tentang budidaya tanaman yang berkualitas dan menjanjikan. Materi yang disampaikan adalah tanaman hias, sayuran dan tanaman obat keluarga (TOGA) sesuai dengan permintaan peserta. Selama pelatihan terlihat banyak peserta kurang memahami pemeliharaan tanaman misalnya jenis unsur dalam pupuk yang dibutuhkan tanaman dan waktu pemupukan. Peserta hanya mengetahui cara menanam saja tanpa pemeliharaan sehingga hasil tanaman tidak maksimal. Adanya pelatihan peserta lebih paham bagaimana langkah-langkah budidaya tanaman sampai panen dengan cara benar baik pada lahan, polybag ataupun system vertikultur. Metode-metode tersebut disesuaikan dengan luas lahan yang dimiliki peserta.

\section{Demplot Budidaya Tanaman di Pekarangan}

Demplot dilakukan pada peserta yang memilik luas lahan $>100 \mathrm{~m}^{2}$, karena budidaya tanaman dilakukan di lahan (Gambar 10). Sedangkan budidaya tanaman di polybag atau system vertikultur dilakukan pada pemilik lahan pekarangan sempit dengan pendampingan. Pendampingan dilakukan secara berkala untuk kesinambungan pemberdayaan lahan pekarangan.

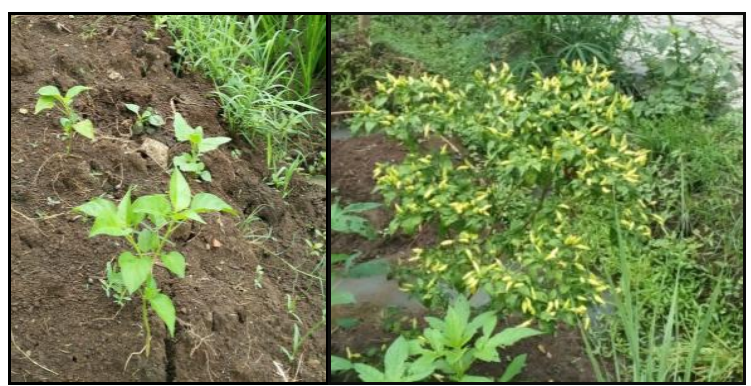

(a)

(b)

Gambar 20. (a) Tanaman Cabai umur 10 hari (b) Produksi Tanaman Cabai di Lahan Pekarangan

Volume 6 Nomor 2 September 2021, DAYA - MAS |84 
Website : http://dayamas.unmermadiun.ac.id/index.php/dayamas

Untuk mengetahui tingkat pemahaman peserta setelah mengikuti pelatihan dilakukan pre dan post test. Hasil test seperti pada Gambar 11.

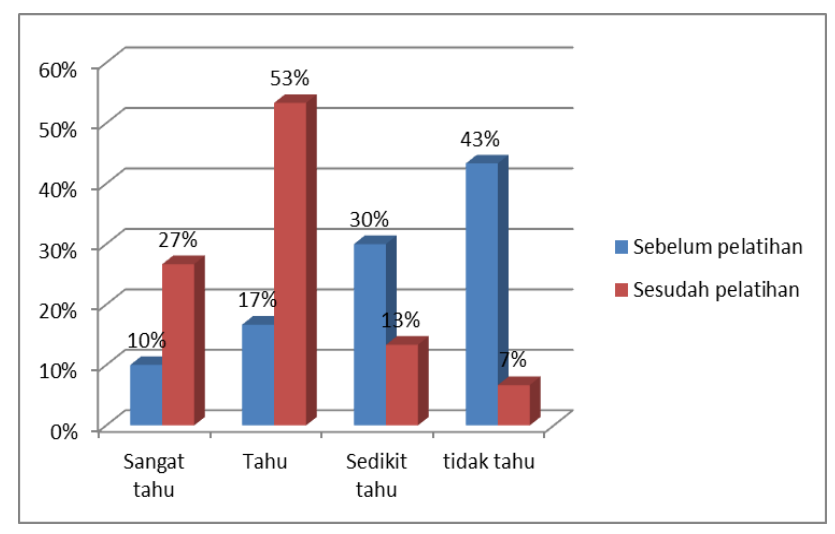

Gambar 11. Hasil Test Sebelum dan Sesudah Pelatihan

Terlihat bahwa persentase peserta yang menjadi lebih tahu setelah mengikuti pelatihan meningkat dari $16.7 \%$ menjadi $53.3 \%$ dan peserta yang tidak tahu persentasenya menurun setelah ikut pelatihan yaitu dari $43.3 \%$ menjadi $6.7 \%$ artinya sosialisasi dan pelatihan ini sangat memberikan daya tarik kepada peserta untuk memanfaatkan lahan pekarangannya. Hasil test akan digunakan untuk menentukan strategi langkah-langkah pendampingan pada peserta yang beragam baik tingkat pendidikan, usia, kepemilikan lahan pekarangan, maupun jenis tanaman yang diinginkan dalam pemberdayaan lahan pekarangan.

\section{KESIMPULAN}

Berdasarkan pelaksanaan kegiatan pengabdian di Kelurahan Banjarejo Kecamatan Taman Kota Madiun, dapat disimpulkan bahwa dari aspek capaian pelaksanaan program pengabdian masyarakat banyak peserta pelatihan yang menginginkan pendampingan. Pendampingan diperlukan saat pelaksanaan kegiatan budidaya, pemeliharaan, panen, dan pemasaran hasil agar pemberdayaan lahan pekarangan berkesinambungan. 
Website : http://dayamas.unmermadiun.ac.id/index.php/dayamas

\section{DAFTAR PUSTAKA}

BPS Kota Madiun. 2020. Kota Madiun dalam Rangka Madiun Municipality In Figures 2020. CV Azka Putra Pratama

BPS Kota Madiun. 2021. Kecamatan Taman dalam Angka 2021. CV Azka Putra Pratama Fityanti, N.E., Luthfi, E. Radiah. 2020. Dampak program Kawasan Rumah Pangan Lestari (KRPL) Terhadap Pengeluaran Rumah Tangga Di Banjarbaru. Frontier Agribisnis 4(2): 93-97

Gunawan, E. dan B. Sayaka. 2020. Imbas Pandemi Covid-19, Bisnis Tanaman Hias Naik Daun. Pusat Sosial Ekonomi dan Kebijakan Pertanian. Kementrian Pertanian. https://pse.litbang.pertanian.go.id/ind/index.php/covid-19/berita-covid19/583-imbaspandemi-covid-19-bisnis-tanaman-hias-naik-daun

Putri, N.P.A., N, Aini, dan Y. B. S. Heddy. 2015. Evaluasi Keberlanjutan Kawasan Rumah Pangan Lestari (KRPL) di Desa Girimoyo, Kecamatan Karangploso, Malang. Jurnal Produksi Tanaman 3(4):278-285

Qomariah, R. 2020. Pemanfaatan Lahan Pekarangan Rumah Di Saat Pandemi Covid-19 Atau Era New Normal. BTPT Kalimantan Selatan. http://kalsel.litbang.pertanian.go.id/ind/index.php?option=com_content\&view=article\&id= 898:administrator\&catid=14:alsin \&Itemid $=43$ Di unduh Agustus 2021.

Tyas, D.N.A. 2019. Implementasi Kebijakan Program Kawasan Rumah Pangan Lestari (KRPL) dalam Meningkatkan Kesejahteraan Masyarakat Jurnal Inovasi Sosial Politik , 1(1): 71-87 